\title{
Impact of External Debt on Economic Growth in Jordan for the Period (2010-2017)
}

\author{
Khaled Abdalla Moh'd AL-Tamimi ${ }^{1} \&$ Mohammad Sulieman Jaradat ${ }^{2}$ \\ ${ }^{1}$ Associate Professor in Economics, Department of Administrative and Financial Sciences, Irbid University \\ College, Al-Balqa' Applied University, Jordan \\ ${ }^{2}$ Associate Professor in Economics, Department of Banking and Financial Sciences, Ajloun National Uniuversity, \\ Jordan \\ Correspondence: Khaled Abdalla Moh'd AL-Tamimi, Associate Professor in Economics, Department of \\ Administrative and Financial Sciences, Irbid University College, Al-Balqa' Applied University, Jordan. E-mail: \\ khaled_tamimi@yahoo.com
}

Received: March 22, 2019

Accepted: March 30, 2019

Online Published: March 31, 2019

doi:10.5539/ijef.v11n4p114

URL: https://doi.org/10.5539/ijef.v11n4p114

\begin{abstract}
The study investigates the effect of external debt on economic growth in Jordan by using annual data for the period (2010-2017) by using external debt as a percentage of gross domestic product (GDP) as an independent variable, and GDP growth rate (A proxy for economic growth) as a dependent variable. The study starts with theoretical literature for the impact of external debt on economic growth, then empirical literature for previous studies that analyze the same relationship, after that analyzing the impact of external debt on economic growth in Jordan during the period (2010-2017). The study finds the same conclusion as previous studies that there is a negative and significant impact of external debt on economic growth during the study period, and recommends relying on other financing methods like foreign direct investment.
\end{abstract}

Keywords: external debt, economic growth, foreign direct investment, budget

\section{Introduction}

External debt is one of financing instruments in any economy. Developing countries depend on external debt to finance its projects because of its low savings and low income. It results in increasing debt service requirements, so external debt accumulates and external debt becomes a constraint and a burden on the economy of a developing country (S. Ayadi \& O. Ayadi, 2008, pp. 234-235). External debt has an ambiguous impact on economic growth; it may be either optimistic or pessimistic. It is useful when it is used for investment purposes in infrastructure such as railway stations. It is detrimental when it is used in consumption purposes that don't benefit the government and increase debts of the country. External debt should be between $35-40 \%$ as a percentage of GDP, and between $160-170 \%$ as a percentage of exports (Shahzad, Zia, Ahmed, Fareed, \& Zulfiqar, 2014, pp. 2133-2134). This study analyzes the impact of external debt on economic growth in Jordan during the period (2010-2017), by starting with theoretical literature of external debt impact on economic growth, then empirical literature of other studies that analyze this relationship, and analyzing the purpose of this study of the impact of external debt on economic growth in Jordan during the period (2010-2017) as follows:

\section{Theoretical Discussion}

The impact of external debt on economic growth can be explained through the debt overhang effect which means that the debt creates debt service obligations that lowers the benefits from external debt in investment projects. This debt overhang effect means increasing debt service in a country that the government couldn't pay and uses its output to pay external debt service so it hinders investment and economic growth (Ejigayehu, 2013, p. 14).

There are 3 theories that explain the effect of external debt on economic growth as follows:

1) Neoclassical Theory

This theory explains the negative impact of external debt on economic growth. Because of increasing budget deficit, the government may use external debt to finance its deficit and those crowds out private investment because of raising interest rates, so it hinders economic growth. 


\section{2) Keynesian Theory}

This theory explains the positive impact of external debt on economic growth. Government tendency to finance its budget by external debt crowds in private investment because of inelasticity of private investment to interest rates, so it increases economic growth.

\section{3) Ricardian Equivalence Theory}

This theory explains that there is no effect of external debt on economic growth as people pays the debt in the future, so it hasn't any impact on interest rates, private investment and economic growth (Ejigayehu, 2013, pp. 15-16).

\section{Literature Review}

There are a lot of studies that analyze the external debt impact on economic growth as follows:

Shahzad, Zia, Ahmed, Fareed, and Zulfiqa (2014) study that studies the external debt impact on economic growth in Pakistan from the period of 1980 to 2013 by using least square multiple regression models. This study found that external debt has a significant and negative impact on economic growth, so Pakistan should go for debt forgiveness and depend on FDI.

S. Ayadi and O. Ayadi (2008) study analyzes the external debt impact on economic growth in Nigeria and South Africa during the period (1994-2007) through ordinary least squares estimation, This study found that there are negative impacts of external debt and external debt service on economic growth in Nigeria and South Africa. The performance in South Africa is better than Nigeria.

Ejigayehu (2013) study analyzes the effect of external debt on economic growth in eight heavily indebted poor African countries during the period 1991 to 2010 through panel data estimation. The study result shows that external debt affects economic growth by the debt crowding out effect rather than debt overhang.

Were (2001) study concentrates on the impact of external debt on economic growth in Kenya during the period (1970-1995) by using ordinary least squares estimation and found that there exists a debt overhang effect in Kenya that external debt has a negative and significant impact on economic growth.

Uchenna, Nwanneka, Adedayo, and Grace (2017) study analyzes effect of external debt on economic growth in Nigeria by using ordinary least squares during the period from 1981 to 2015 . This study found that external debt has a significant and positive effect on economic growth. This result indicates that this debt was used fotinvestment projects not consumption projects.

Ibrahim (2013) study concentrates on studying the impact of external debt on economic growth in four East African countries (Kenya, Tanzania, Uganda, and Rwanda) for the period 1981 to 2014 using the fixed effect and the random effects model estimation techniques. The study found a negative and significant impact of external debt on economic growth.

Kharusi and Ada (2018) study analysis the impact of external debt on economic growth in Oman during the period (1990-2015) through the Autoregressive Distributed Lag cointegration approach and found that external debt has a negative effect on economic growth.

Mahmoud (2015) study studies the impact of external debt on economic growth in Mauritania during the period (1989-2012) by using ordinary least squares and found that external debt has a significant and negative impact on economic growth.

From the previous studies, we can say that most of these studies found a negative and significant impact of external debt on economic growth. This may indicate that all these countries use external debt for consumption not investment purposes.

\section{Impact of External Debt on Economic Growth in Jordan During the Period (2010-2017)}

\subsection{Method}

The study uses annual data for the period (2010-2017) for external debt and economic growth variables in Jordan. The following equation presents the impact of external debt on economic growth:

$$
\text { Economic growth } h_{t}=\alpha_{0}+\alpha_{1} \text { External debt }_{t}+\varepsilon_{t}
$$

\subsection{Results}

This section concentrates on analyzing external debt, external debt service and economic growth in Jordan during the period (2010-2017) as follows: 


\subsubsection{External debt in Jordan}

Table 1. External debt as a percentage of GDP in Jordan (\%) during the period (2010-2017)

\begin{tabular}{cc}
\hline Year & External debt as a percentage of GDP \\
\hline 2010 & 65.1 \\
2011 & 61.8 \\
2012 & 60.5 \\
2013 & 69.7 \\
2014 & 68.6 \\
2015 & 69.4 \\
2016 & 71 \\
2017 & 75.3 \\
\hline
\end{tabular}

Source: Researcher conducting depending on World bank data.

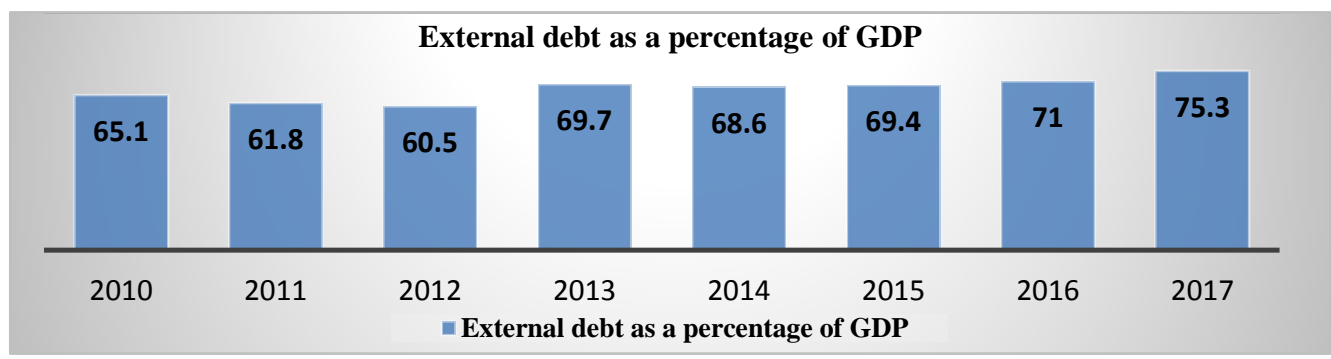

Figure 1. External debt as a percentage of GDP in Jordan (\%) during the period (2010-2017)

Source: World bank data.

The table and figure above show External debt as a percentage of GDP in Jordan (\%) during the period (2010-2017). They indicate that external debt percentage to GDP increases from $65.1 \%$ in 2010 to $75.3 \%$ in 2017 with average of $67.7 \%$ during the whole period. Its effect on economic growths depends on its uses in consumption or investment purposes.

\subsubsection{External Debt Service in Jordan}

Table 2. External debt service as a percentage of GDP in Jordan (\%) during the period (2010-2017)

\begin{tabular}{cc}
\hline Year & External debt service as a percentage of GDP \\
\hline 2010 & 3 \\
2011 & 3.3 \\
2012 & 3.1 \\
2013 & 2.8 \\
2014 & 3.8 \\
2015 & 5.7 \\
2016 & 6.4 \\
2017 & 4.7 \\
\hline
\end{tabular}

Source: World bank data.

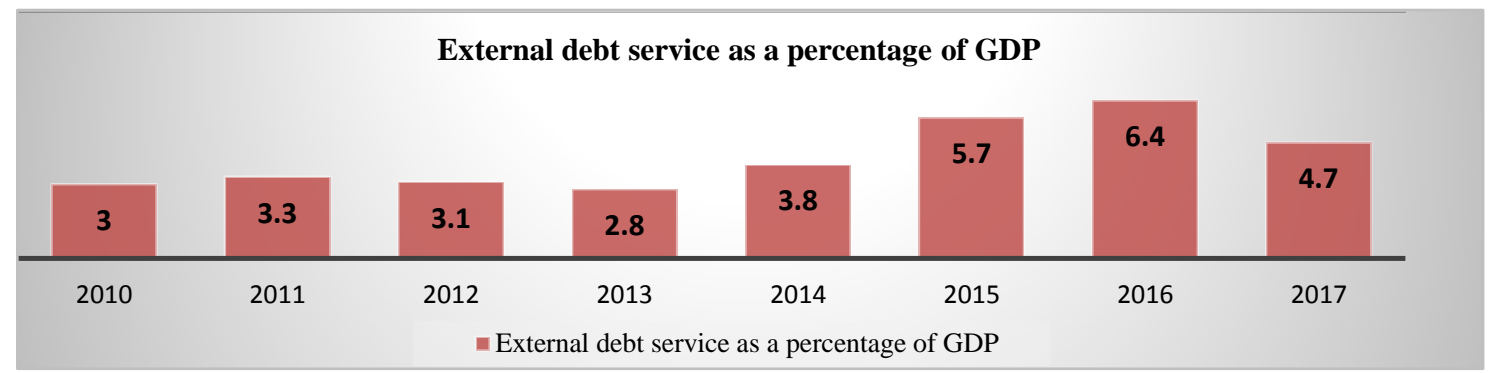

Figure 2. External debt service as a percentage of GDP in Jordan (\%) during the period (2010-2017) Source: World bank data. 
Table and Figure 2 present External debt service as a percentage of GDP in Jordan (\%) during the period (2010-2017). They indicate that percent of external debt service to GDP increases from $3 \%$ in 2010 to $6.4 \%$ in 2017, but it decreases in 2017 as it reaches $4.7 \%$ with average of $4.1 \%$ during the whole period.

4.2.3 GDP Growth Rate (As an Indicator of Economic Growth) in Jordan

Table 3. GDP Growth rate in Jordan (\%) during the period (2010-2017)

\begin{tabular}{cc}
\hline Year & GDP growth rate \\
\hline 2010 & 0.004 \\
2011 & 2.5 \\
2012 & 2.3 \\
2013 & 3.1 \\
2014 & 3 \\
2015 & 2.4 \\
2016 & 2.3 \\
2017 & 2.2 \\
\hline
\end{tabular}

Source: World bank data.

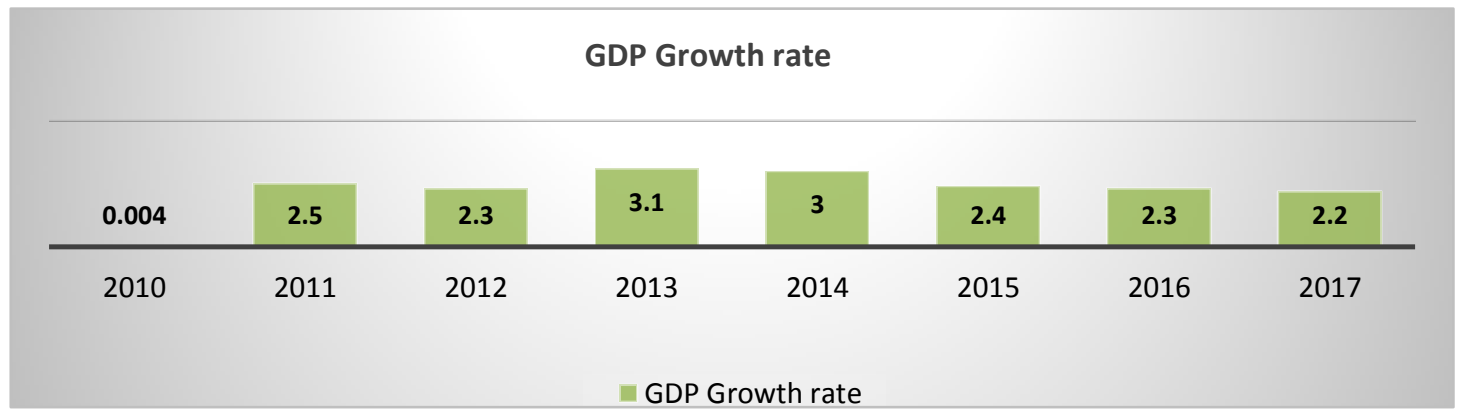

Figure 3. GDP growth rate in Jordan (\%) during the period (2010-2017)

Source: World bank data.

Table and Figure 3 show GDP growth rate in Jordan (\%) during the period (2010-2017). They indicate that GDP growth rate increases during the first phase of period from $0.004 \%$ in 2010 to $3.1 \%$ in 2013 , but it decreases through the second phase of this period to $2.2 \%$ in 2017 , with average of $2.2 \%$ during the whole period. To know the impact of external debt on economic growth, we shall use this figure:

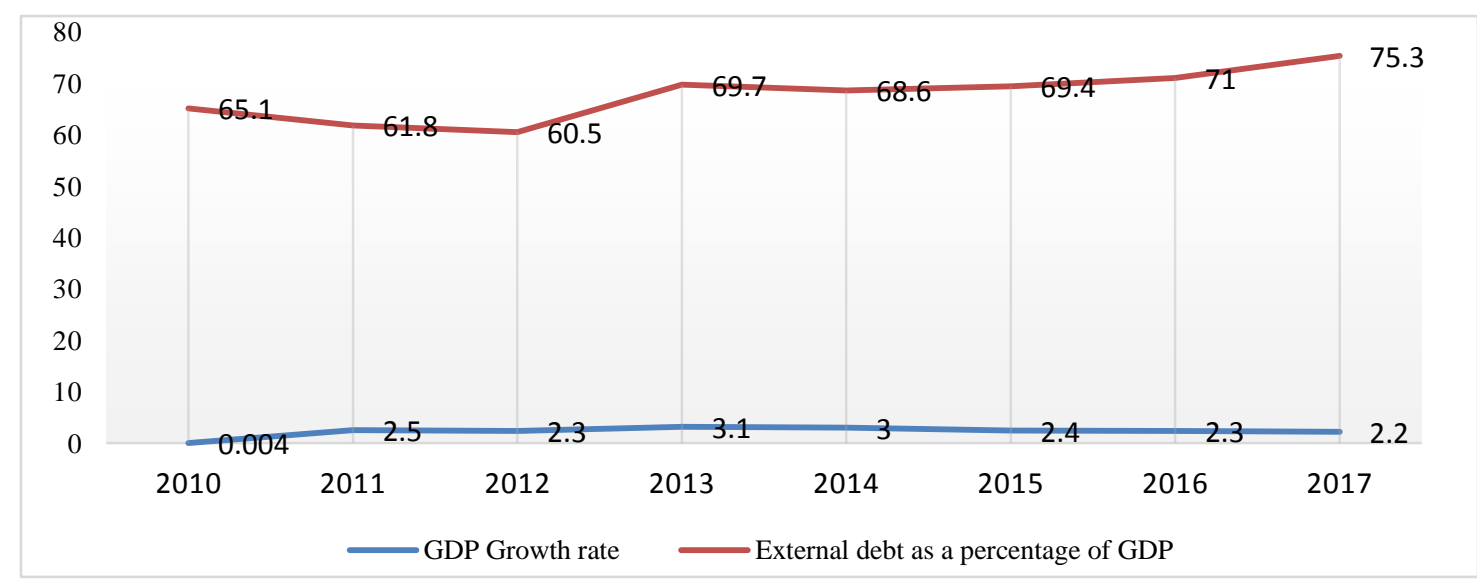

Figure 4. External debt as a percentage of GDP and GDP growth rate in Jordan (\%) during the period (2010-2017) 
Figure 4 indicates the relationship between external debt and economic growth in Jordan during the period (2010-2017). The figure above shows a negative relationship between external debt and economic growth in Jordan; as when external debt increases, economic growth decreases and vice versa.

\section{Conclusion and Recommendations}

This study analyzes the Impact of external debt on economic growth from theoretical and empirical literature, and this impact in Jordan during the period (2010-2017). The study found a negative relationship between external debt and economic growth in Jordan during the period (2010-2017).

The study recommends depending less on external debt because of its negative effect on economic growth and relying more on foreign direct investment.

\section{References}

Ejigayehu, D. (2013). The Effect of External Debt on Economic growth. Sodertorn University. Retrieved from http://www.diva-portal.org/smash/get/diva2:664110/FULLTEXT01.pdf

Ibrahim, H. (2013). Effect of External Public Debt on Economic Growth: An Empirical Analysis of East African Countries. Master thesis, University of Nairobi.

Kharusi, S., \& Ada, M. (2018).External Debt and Economic Growth: The Case of Emerging Economy. Journal of Economic Integration, 33(1).https://doi.org/10.11130/jei.2018.33.1.1141

Mahmoud, L. (2015). The Role of External Debt on Economic Growth: Evidence from Mauritania. International Journal of Economics \& Management Sciences. https://doi.org/10.4172/2162-6359.1000240

S. Ayadi, F., \& O. Ayadi, F. (2008). The Impact of External Debt on Economic Growth: A Comparative Study of Nigeria and South Africa. Journal of Sustainable Development in Africa, 10(3).Retrieved from https://www.academia.edu/3178377/THE_IMPACT_OF_EXTERNAL_DEBT_ON_ECONOMIC_GROW TH_A_COMPARATIVE_STUDY_OF_NIGERIA_AND_SOUTH_AFRICA

Shahzad, F., Zia, A., Ahmed, N., Fareed, Z., \& Zulfiqar, B. (2014). Impact of External Debt on Economic Growth: A Case Study of Pakistan. Russian Federation European Researcher, 89(12-2), 2133-2140.

Uchenna, O., Nwanneka, M., Adedayo, E., \& Grace, E. (2017). Effect of External Debt on Economic Growth: Evidence from Nigeria. Covenant University. Retrieved from http://eprints.covenantuniversity.edu.ng/10184/1/Binder1.pdf

Were, M. (2001).The Impact of External Debt on Economic Growth in Kenya. United Nations University, Discussion paper No. 116.

World bank data for Jordan. Retrieved from https://data.worldbank.org/country/jordan

\section{Copyrights}

Copyright for this article is retained by the author(s), with first publication rights granted to the journal.

This is an open-access article distributed under the terms and conditions of the Creative Commons Attribution license (http://creativecommons.org/licenses/by/4.0/). 